\title{
Supply Chain Practices And Challenges In The Craft Industry In Gauteng, South Africa
}

Khathutshelo M. Makhitha, University of South Africa, South Africa

\begin{abstract}
Craft producers in South Africa (SA) face many challenges including supply chain challenges. There is no existing study that has investigated the supply chain management of the craft industry in SA. There is also dearth of literature on supply chain management of small businesses. The purpose of this study was to investigate the supply chain practices and challenges of craft producers in South Africa. A survey was conducted among 199 craft producers in Gauteng, South Africa. A convenience sampling method was adopted owing to the difficulty of accessing a reliable database of craft producers. Craft producers rely mainly on telephones for customers to place orders. However, they use variety of methods for order placement. Customers are allowed to also visit the factory to buy products and they can buy at the exhibition. They use a variety of production methods. Due to transportation challenges, craft producers also make use of public transport to deliver goods and keep some products at the warehouse.
\end{abstract}

Keywords: Supply Chain Management; Production Strategy; Order Placement; Transportation; Warehouse/Factory; Inventory Management; Craft Producers; Small Businesses

\section{INTRODUCTION}

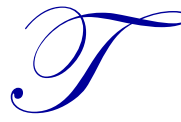

he Department of Trade and Industry (2005) define craft as "the creation and production of a broad range of utilitarian and decorative items produced on a small scale with hand processes being a significant part of the value added content. The production of goods uses a range of natural and synthetic materials". Products produced in the industry include home furnishing, jewellery, fashion and fashion accessories, novelties and gifts including corporate gifts, garden and outdoor, curios, collectibles, one of a kind, high value, individually made objects and indigenous artefacts, as well as culturally derived objects (Department of Trade \& Industry, 2005). Craft production usually is initiated in regions where it is still regarded as a way of life. Craft product designs are traditional and functional in nature (Wesgro, 2000:4). Regions such as Gauteng and the Western Cape have the highest population of crafters because of urbanisation and the fact that they have an established tourism industry (Wesgro, 2000).

The craft industry is highly significant due to the employment it creates, and incorporates both informal craft producers selling on the roadside and formal craft producers that sell their products locally and internationally (Elk, 2004). The craft industry contributes R2 billion to the gross domestic product (GDP) in the craft industry value chain (Kaiser \& Associates, 2005) and consists of over $7000 \mathrm{craft}$ producer businesses (Department of Trade and Industry, 2005). The industry employs 40000 people (DED and SEDA cited in McCarthy \& Mavundla, 2009). The local market has shown a strong growth of between 3 to 4 percent annually, and the sector contributes 0.14 percent to the GDP, of which R150 million is from export sales. The number of craft producer businesses has also increased by 40 percent, with an average growth of 8 percent per year, double the national average (Department of Labour, 2008). The SA government spent R97 million on the establishment and growth of the craft industry in SA between 2001 and 2003 (Create SA cited in Grobler, 2005), making this an important sector. 
Craft producers lack the skills necessary to conduct and run businesses. As a result, they are unable to identify market opportunities and, where they are able to do so; they are unable to pursue them because of their limited skills (Department of Sports, Arts, Recreation \& Culture, 2007). Due to the lack of skills and limited access to resources, they are unable to match the quality standards and production capacity needed by their customers. For example, formal craft retailers have to deal with informal craft producers who lack understanding of what they (craft retailers) are look for (Broembsen, 2011). The craft industry has a high level of diversity in comparison with other industries in SA. Raw materials, scale of production, product types and quality vary across the industry (Rogerson, 2010:131). Furthermore, the quality standards, scales of production as well as craft product positioning differ for different products (DTI, 2005:85). Craft producers with unique products face less competition and are able to sell their products in high numbers (Perreira et al., 2006:483). The industry is highly fragmented with the majority of craft producers being sole traders or small informal producers and cooperatives (Department of Economic Development, 2009:5).

In SA, the number of craft producers increased by an estimated 40 percent between 2005 and 2009, with an average growth of 8 percent per year. Growth was attributed to growth in tourism (SouthAfricaWeb). This is an indication that there are growing market opportunities for craft producers both locally and internationally. Growth in the craft market is associated with the rise in local interest in SA craft fuelled by trends towards ethnic, rustic, earthy African styles, increasing national pride and the return of African values (Sellschop, Goldblatt, \& Hemp, 2005). The growth of the black middle class and its ability to earn and spend its income on goods and services has also impacted on the growth in this market (Wesgro, 2000). However, such opportunities cannot materialise unless craft producers are competitive. Craft producers need an effective and efficient supply chain that will get the right product at the right time and at the right place.

Craft products are sold through formal and informal retail channels. The formal retail channels consist of various retail outlets such as those in formal craft markets, and formal large and small retailers ranging from boutique shops and gift shops to large outlets in airports as well as national retailers such as Mr Price Home, Pep Home and Woolworths (Department of Sports, Arts, Recreation \& Culture, 2007). The informal retail channels consist of those involved craft producers selling directly to consumers such as the street hawkers operating alongside the Tshwane Zoo in Tshwane, South Africa.

Formal craft retailers consequently form an important part of the value chain. Retailers provide access points to the consumer market for most products (Collins \& Burt, 2003). This makes selling to formal craft retailers and an understanding of an effective and efficient supply chain practice of great significance to craft producers, since it will help them create competitive advantages for their businesses and gain access to a bigger share of the market.

\section{LITERATURE REVIEW}

Supply chain management (SCM) is a key to success for any businesses as purchased goods and services account for 80 percent of sales revenue (Quayle, 2003). Managing SCM can create a competitive advantage as well greater profit for businesses (Chen \& Li 2006, Li 2006; Cooper \& Ellram, 1993). SCM and related strategies are crucially important to the success of a manufacturing firm because the cost and quality of goods and services sold are directly related to the cost and quality of goods and services purchased (Koh, Demirbag, Bayraktar, Tatoglu \& Zaim, 2007). Building effective supply chains offers businesses opportunities to create sustainable competitive advantage (Cooper, Lambert \& Pagh, 1997). SCM impact on key competitive dimensions such as product availability, order to delivery cycle time, costs, and customer service (Tracey, Lim \& Vonderembse, 2005).

The Global Supply Chain Forum defines the supply chain as the integration of key business processes from the end user through to original suppliers, and which provides products, services and information that add value for customers and other stakeholders (Lambert \& Cooper 2000). This definition includes upstream linkages, such as sources of supply, the internal linkages inside the business and downstream linkages such as distribution to ultimate customers. These activities are concerned with the integration of business processes from end user through to original suppliers that provide products, services and information and add value for customers (Burt Petcavage. \& Pinkerton, 2012; Mangan Lalwani, Butcher, \& Javadpour, 2012; Trott 2012:412; Hugo \& Badenhorst-Weiss 2013). 
Hilletofth (2009) define supply chain management as a set of approaches utilised to efficiently integrate and coordinate the materials, information and financial flow across the supply chain so that merchandise is supplied, produced and distributed at the right quantities, to the right location, at the right time, in the most cost efficient way, whilst satisfying customer requirements. According to Pienaar and Vogt (2012), the purpose of supply chain management is to create value, enhance efficiency, and to satisfy customers.

There are four major components of an SCM:

- The flow of physical materials from suppliers, downstream through the business itself and finally to distributors and/or customers

- $\quad$ The flow of money upstream from customers back to companies and suppliers

- The flow of information up and down the stream

- $\quad$ The flow of products back (upstream) from the customers, typically for repair or recycling (Arnold, Slama \& Sisler, 2012).

This research will focus on the first component, with specific focus on the downstream linkages, to determine the supply chain practices of craft producers. Furthermore, Sutherland \& Canwell (cited in Pienaar \& Vogt 2012) define supply chain as the integrated management and control of the flow of information, materials and services from suppliers of raw materials, through to the factories, warehouses and retailers, to the end customers. SCM offer several benefits including product and delivery process quality such as shorter delivery times, more reliable delivery promises, fewer schedule disruptions, cost savings (for example, significant reductions in inventories) and risk reductions (Bask \& Juga, 2001).

Supply chain include all the activities involved in delivering a product from raw material through to the customer including sourcing raw materials and parts, manufacturing and assembly, transportation, warehousing and inventory tracking, order entry and order management, distribution across all channels, delivery to the customer, and the information systems necessary to monitor all of these activities (Lummus \& Vokurka, 1999; Tan, 2001). Grant, Lambert, Stock and Ellram (2006) grouped the SCM activities as consisting of customer service and support; demand forecasting and planning; purchasing and procurement; inventory management; order processing and logistics communications; material handling and packaging; transportation; facilities site selection, warehousing and storage and return goods handling and reverse logistics. Chan and Qi (2003) suggested that supply chain activities include supply base management; inbound material transportation and storage; outbound transportation and distribution; manufacturing; warehousing and marketing and sales. SCM can benefit businesses both in the short term and long rum. Its short-term objective is to increase productivity and reduce inventory and cycle time, while the long-term strategic goal is to increase customer satisfaction, market share, and profits (Tan, 2006). The purpose of this study is to investigate the supply chain practices of craft producers in South Africa. Specifically, the research will investigate the SCM activities such as the production strategy, distribution, order placement, warehouse/factory space, transportation and inventory management. This will determine how craft businesses perform and practice the activities in the supply chain.

The quality of the SCM activities of production, warehousing, inventory control, and outbound transportation has important repercussions regarding the firm's capacity to satisfy customers. For businesses to please customers, they need to produce and deliver the right product at the right time and at the right place (Tracey et al, 2005). This implies that businesses must have certain abilities to keep the stock at the warehouse for delivery as and when customers need them. Transportation maintains the flow of goods from the plant, through the distribution network and to the final customer and impact on customer satisfaction. The choice of the transportation method used determines how effective transportation will be and has impact on the product's cost (Thompson \& Manrodt, 1997).

Productive and profitable businesses examine their internal as well as external processes for the creation and distribution of goods and services. This enable manager to access the value of activities in each process and determine how to increase the value of these activities that form a value chain from supplier to firm to distributor to customer (Beheshti, Hultman, Jung, Opoku \& Salehi-Sangari, 2007). 
Beheshti, Hultman, Jung, Opoku and Salehi-Sangari Beheshti, Hultman, Jung, Opoku and Salehi-Sangari (2007) conducted a study on the use of internet in the SCM by small businesses. The study found that small businesses use internet mainly for purchasing, followed by customer service and customer order processing. The findings differed from those of Lacione, Smith \& Oliva (2000) who found that SMEs use internet for the management of transportation services followed by order processing and purchasing a well as relating with customers. According to Beheshti et al (2007), inventory management is the most important area of the supply chain management. The most common SCM practices among SMEs are the holding of safety stock and sub-contracting to cope with uncertainties in a supply chain (Koh \& Tan, 2006). However, SMEs may not have the required capacity and resources to maintain safety (Bayraktar, Demirbag, Koh, Tatoglu \& Zaim, 2009).

Most multinational corporations are pursuing different operations strategies to secure market share and improve profits due to increasing global competition and a decline in profit margins (Gunasekeran \& Ngai, 2005). By working closely with suppliers, inventories of components and materials are minimized. Building products to order means that there is no finished product inventory in the channel to manage (Bowersox, Stank \& Daugherty, 1999).

Customer satisfaction is influenced by the quality of the manufacturer's outbound transportation service. It maintains the flow of finished goods from the plant, through the distribution network, and often concluding with delivery to the final customer. Its effectiveness depends on choices made concerning the method of shipment, the specific carrier(s) used, the route, and compliance with local, state, federal, and international regulations. Even though it accounts for a significant share of a product's cost and is critical to customer satisfaction, transportation is often the missing link in SCM (Thompson \& Manrodt, 1997).

The advancement in Internet technology has created many opportunities for large and small enterprises. The Internet is a low-cost way of conducting economic activities (De Klerk \& Kroon, 2005). It provides a number of benefits including email messaging, communication with customers, placing business and product information on the Internet, access to product and component information, search for new suppliers, gathering of information about current suppliers, providing information to suppliers, gathering competitive information and online ordering (Cloete, Ourtney \& Fintz, 2002; Osmonbekov, Bello \& Gilliland, 2002). Suppliers can also post information about their products and businesses and allow for the placement and filling of orders, and facilitate product delivery and service performance (Gilmore, Gallagher \& Henry, 2007).

The Internet has become the most important medium for craft producers (United Nations Educational Scientific \& Cultural Organisation, 1997) and can bring enhancement to craft producers that are willing and able to integrate their marketing and daily operations (Batchelor \& Webb 2002). Internet adoption could give small businesses a wider market access since they can reach customers across the globe that they would otherwise not be able to reach owing to resource limitations. Internet adoption also helps enterprises to gather information about their customers, to keep abreast of changes in consumer behaviour as well as to gain new product ideas (Migiro \& Ocholla 2005). The Internet-based supply chain management provides many opportunities for businesses and includes streamlining the supply chain, improving speed, lowering costs and to be more flexible ((Lankford 2004). It improves communications among customers and suppliers and can also smooth the existing flow of goods and services throughout the supply chain (Lancioni et al., 2003).

\section{Small and Medium Businesses (SMEs) and the Supply Chain}

Research on supply chain has focused to a large extent on large businesses (Burt et al, 2012). There is dearth of literature on small business supply chain management. Small businesses do not have an effective supply chain management (SCM) (Vaaland \& Heide, 2007). They end up being reactive instead of proactive in their supply chain. This in turn creates supply chain and logistic challenges for them (Voortman \& Makhitha, 2014). SMEs are not able to implement SCM fully because they are managed at arm's length by larger customers and have to follow the norms stipulated by the buyer (Arend \& Wisner, 2005). They are known to have few products, few customers and low volume, lacking economies of experience and learning capacity, being bounded rational, having higher capital and transaction costs, having a reactive nature, being technologically focused with weak marketing skills and having limited resources (Coviello \& McAuley, 1999; O'Gorman, 2001). 
Thakkar, Kanda and Deshmukh(2008) define supply chain from a small business perspective as a set of business activities including purchase from open/spot market, manufacturing or processing of subcomponents/subassembly within the plant and delivery to large enterprises using hired transportation to enhance value of end product and in-turn to ensure long-term regular purchase orders.

Supply chain inefficiency is one of the most prevalent issues facing the small- to mid-size enterprise (Lewis, 2005). SCM can provide quality, cost, customer service, leverage and even risk reduction benefits for the SMEs but exposes the SME to greater management and control hazards while reducing its private differentiation advantages (Arend \& Winser, 2004). Purchasing seems to have received little attention from owner-managers and was ranked 14 out of a total 19 attributes valued by SMES owner-managers when managing their firms (Quayle, 2000). SMEs face severe pressure to produce the "best" product, at the cheapest price, and with the shortest manufacturing lead time (Thakkar et al., 2008).

SMEs are less likely to harness the benefits of SCM and also experience difficulties in implementing SCM practices (Vaaland \& Heide, 2007). SMEs do not implement SCM deeply as much as the large businesses. SMEs lack of effective adoption of SCM techniques and ignore issues such as new technology, R\&D and ecommerce, which are normally associated with innovations in a supply chain context (Quayle, 2003). However, SMEs consider email order processing as important in future (Vaaland \& Heide, 2007).

\section{Problem Statement and Objectives}

The craft industry is dominated by small and medium craft producer businesses (Hay, 2008). There is a lack of reliable and accessible research data (Department of Economic Development, 2009), which impedes the industry's development and competitiveness. Supply chain and logistics are the major challenges facing the industry (Department of Sports, Arts, Recreation \& Culture, 2007). Craft producers face difficulties selling their products due to lack of access to production and retail space, lack of access to equipment and raw materials, lack of access to information, marketing and markets, lack of access to finance and lack of access to transportation (Department of Sports, Arts, Recreation \& Culture, 2007).

Although some research has been conducted on the craft industry in South Africa, no research studies exist on the supply chain practices and challenges of the craft producers in South Africa. Existing research focused on marketing of craft products and include craft product development by design (Rankin, 2007), product development strategies for community craft projects in Mpumalanga (Grobler, 2005) and the importance of a market-led approach to the growth and sustainability of craft businesses (Obiri, 2002). Additional studies include craft marketing strategies in roadside Kwazulu-Natal (KZN) (Dludla, 2005), craft retailers' supplier selection criteria -a key to market access (Makhitha, Wiese, Van Heerden, 2014), reflections on the constraints in entrepreneurial development among emerging survivalist and micro craft enterprises in Gauteng (Dhurup \& Makhitha, 2014) and increasing South Africa's contribution to the global trade in craft (Sujee, 2008).

Voortman and Makhitha (2014) studied the integration of supply chain and product strategy of craft producers. It was found that the supply chain and logistic efficiency of the small craft businesses was very poorly defined and that they could not afford or utilise transport and storage optimally. The purpose of this research was to investigate the supply chain practices of craft producers in South Africa. Specifically this research will:

- determine the supply chain practices of producers in the craft industry

- $\quad$ determine the SCM challenges facing the craft industry in SA.

\section{Research Methodology}

The study adopted a survey method targeted at craft producers in Gauteng, South Africa. This included craft producers producing different types of products. A non-probability convenience sampling method was adopted owing to the difficulties of identifying craft producers and the fact that there was no reliable and easily accessible database of craft retailers. The convenience sampling method is suitable when there are time constraints and lists of available units are either incomplete and not up-to date, as with the case of SA craft producers (Cooper \& Schindler, 2006). 
Data were collected using bachelor of technology logistics students from a university of technology. Students were trained to perform their fieldwork duties. Data were collected from either owners or managers of the businesses. Since the study adopted the convenience sampling method, craft producers that were located in flea and craft markets were targeted for the sample. Flea and craft markets are the places most visited by tourists and other consumers looking for craft products. A total of 250 questionnaires were completed, however, only 199 of them were considered usable. The other questionnaires were discarded because they were either incomplete or many had missing answers. This yielded a response rate of 80 percent.

A questionnaire was developed based on the literature of previous studies, including government sources such as reports from the South African Craft Industry and Department of Trade and Industry. There were 40 questionnaire items, which measured five constructs: production strategy, distribution, order placement, warehouse/factory space, transportation, inventory management and Internet adoption. Questions were formulated in Likert-scale format with $1=$ strongly disagree, $2=$ disagree, $3=$ moderately agree, $4=$ agree and $5=$ strongly agree. There were six items measuring production strategy, four measuring distribution, six measuring order placement, seven measuring warehouse/factory space, five measuring transportation, six measuring inventory management and six measuring Internet adoption. There were two demographic items in the questionnaire, one measuring the length of time the business was in operation and the other determining the number of workers employed by each enterprise.

Data were analysed using SPSS version 22. Descriptive statistics and factor analysis were conducted and the results are reported and discussed in the next section.

\section{Reliability and Validity}

The reliability assessment for the supply chain instrument was ascertained by computing the Cronbach alpha coefficient values. According to Malhotra (2010), Cronbach alpha coefficients of less than 0.50 are deemed unacceptable; those between 0.50 and 0.69 are considered as being adequate, whereas those above 0.70 are regarded as being acceptable in social science enquiry. The sub-scale reliability values ranged between 0.345 and 0.904 , while the standardised Cronbach alpha value for the entire scale was established at 0.785 , indicating an acceptable level of internal consistency among the scale items.

Content validity is the representativeness of the content of the measurement instrument (Malhotra, 2010). The questionnaire was pilot-tested with a sample of 30 conveniently selected respondents in order to check the wording, phrasing and language appropriateness of the questionnaire items. Exploratory factor analysis was conducted with a view to establish construct validity of the scale. There were no cross-loadings among the factors, thus providing evidence of discriminant validity (items loading on each construct were theoretically dissimilar from those loading on the other constructs) as suggested by Zikmund \& Babin (2007).

\section{RESULTS}

\section{Descriptive Statistics}

The sample consisted of craft producers operating in Gauteng province, South Africa. Of the 199 craft producers, majority $(30 \%, n=61)$ of them have been operating for between three and five years. This was followed by those that have been in operation for between six and 10 years and were represented by 25 percent $(n=50)$ of the respondents. This is shown in Table 1 . Since craft producers are mostly small businesses, the majority $(58 \%, \mathrm{n}=96)$ of the businesses employ two and five persons, followed by those who work by themselves $(37.7, \mathrm{n}=75)$. 
Table 1. Demographic profile of respondents

\begin{tabular}{clccc}
\hline Variable & \multicolumn{1}{c}{ Categories } & Population & Sample frequency & Percentages \\
\hline & Less than 1 year & 199 & 11 & 5.5 \\
& Between 1 and 2 years & 199 & 28 & 14.1 \\
Years of business operation & Between 3 and 5 years & 199 & 61 & 30.7 \\
& Between 6 and 10 years & 199 & 50 & 25.1 \\
& More than 10 years & 199 & 49 & 24.6 \\
\hline \multirow{5}{*}{ No of people employed } & I person- myself & 199 & 75 & 37.7 \\
& 1-5 persons & 199 & 96 & 48.2 \\
& 6 to 10 persons & 199 & 16 & 8.0 \\
& More than 10 people & & 3 & 1.5 \\
\hline
\end{tabular}

Table 2 depicts the mean and standard deviation of the variables. As can be seen from the table, craft producers place more emphasis on order placement and inventory management. The mean scores for 'customers can order the product over the phone' is 3.86, higher than for all the SCM activities listed in the table. This is followed by the inventory management practice 'keep enough stock to supply as and when there is an order' which has a mean score of 3.81. Another important practice for craft producers is 'design and produce products according to customer specification' $M=3.77$ followed by 'customers visit the factory whenever they want to buy' $(M=3.66)$. Craft producers use less rail transport to deliver their goods $(\mathrm{M}=2.01)$. Due to lack of access to own transportation, craft producers make use of public transportation to deliver goods to customers. They use Internet less to sell and advertise their products $(\mathrm{M}=2.39)$. Overall, internet adoption is moderately practiced by craft producers.

Table 2. Descriptive statistics: Mean and standard deviation

\begin{tabular}{|c|c|c|c|}
\hline Variable & Variable description & $\mathbf{M}$ & SD \\
\hline \multirow{6}{*}{$\begin{array}{l}\text { Production } \\
\text { strategy }\end{array}$} & Produce few products at a time & 3.11 & 1.293 \\
\hline & Produce products as and when we receive the order & 3.11 & 1.384 \\
\hline & Produce products to keep in the warehouse & 3.43 & 1.270 \\
\hline & Design and produce products according to customer specification & 3.77 & 1.264 \\
\hline & Do not have access to production machinery & 3.23 & 1.390 \\
\hline & We cannot produce in bulk & 2.77 & 1.303 \\
\hline \multirow{4}{*}{ Distribution } & Customers come collect products at the factory & 3.42 & 1.305 \\
\hline & Products are delivered to the customers & 3.14 & 1.240 \\
\hline & Products are couriered to international customers & 2.97 & 1.548 \\
\hline & Customers buy and collect products at the exhibition & 3.64 & 1.235 \\
\hline \multirow{6}{*}{ Order placement } & Customers visit the factory whenever they want to buy & 3.66 & 1.325 \\
\hline & Customers can order the product over the phone & 3.86 & 1.221 \\
\hline & Customers can order the product by email & 2.85 & 1.463 \\
\hline & Customers can order the product at the exhibitions & 3.53 & 1.346 \\
\hline & Customers can order the product via the Internet & 2.67 & 1.449 \\
\hline & It is sometimes difficult for customers to contact us when they want to place orders & 2.53 & 1.202 \\
\hline \multirow{7}{*}{$\begin{array}{l}\text { Warehouse/ } \\
\text { factory space }\end{array}$} & Have my own space & 3.56 & 1.326 \\
\hline & I share the space with others the space & 3.22 & 1.381 \\
\hline & Use space provided by government buy pay for it & 2.69 & 1.396 \\
\hline & Warehouse and production space pose a major challenge for my business & 3.16 & 1.357 \\
\hline & Renting out the space is very expensive & 3.44 & 1.408 \\
\hline & There is not enough space to keep the stock & 3.31 & 1.344 \\
\hline & It is difficult to find a less expensive space for rental & 3.56 & 1.379 \\
\hline \multirow{5}{*}{ Transportation } & Use my own transport & 3.48 & 1.430 \\
\hline & Hire a delivery vehicle as and when there is an order to deliver & 2.79 & 1.310 \\
\hline & Use public transport to deliver goods to customers & 2.55 & 1.322 \\
\hline & Use rail transport to deliver our goods & 2.01 & 1.111 \\
\hline & Transportation is one of the major challenges facing my businesses & 3.06 & 1.434 \\
\hline
\end{tabular}




\begin{tabular}{llrc} 
(Table 2 continued) & & & \\
\hline \multicolumn{1}{c}{ Variable } & & Variable description & M \\
\hline & Keep enough stock to supply as and when there is an order & 3.81 & 1.187 \\
Inventory & Produce products as and when there is an order & 3.27 & 1.140 \\
management & It takes us two weeks to produce products for big orders & 3.09 & 1.101 \\
& Do not have enough space to keep our products & 3.02 & 1.305 \\
& It cost us more to keep the stock & 3.02 & 1.323 \\
& Customers sometimes require more stock than we have available & 3.32 & 1.311 \\
\hline Internet & Have access to own Internet & 2.69 & 1.454 \\
& Access Internet at the Internet café & 2.83 & 1.320 \\
& Use Internet to sell and advertise the products & 2.39 & 1.319 \\
& Use of email to communicate with customers & 2.67 & 1.358 \\
& Internet is useful for our businesses & 2.90 & 1.438 \\
& Use of email to communicate with suppliers & 2.60 & 1.387 \\
\hline
\end{tabular}

\section{Factor analysis}

Factor analysis was conducted to ascertain whether the variables developed from a review of the literature and from the preliminary qualitative research could, in fact, be grouped into meaningful dimensions to describe the supplier selection criteria and sources of information. The main purpose of factor analysis is to define the underlying structure among variables in the analysis (Hair et al., 2010). The principal component factor analysis with varimax rotation was performed. Principal component analysis establishes which linear components exist within data and how each variable contributes to that component (Field \& Miles, 2010).

Prior to performing the factor analysis, the suitability of the data for factor analysis was assessed. Pallent (2010) states that, ideally, the overall sample size should be over 150 for factor analysis; therefore, the sample size for this study of 199 was deemed sufficient. The Bartlett test was used to test the overall significance of all correlations within the correlation matrix (Hair et al., 2010). It evaluates all factors and each of the factors is evaluated separately against the hypothesis that there are no factors (Tabachnik \& Fidell, 2001). The Kaiser-MeyerOlkin (KMO) measure of sampling adequacy of 0.716 indicated that the data were suitable for factor analysis. According to Field \& Miles (2010), a KMO closer to one indicates the patterns of correlations that are relatively compact and that factor analysis could yield distinct and reliable factors. Items with factor loading of 0.5 were considered part of the variables and those with less than 0.5 were omitted.

The total variance explained by the extracted factors was 64.46. As guided by Kim and Mueller (1978), the threshold of 0.37 to 0.82 was maintained on the communalities, as well as a cut-off point of 0.30 on the item-to-total correlations. This resulted in nine items being dropped from factor analysis after they loaded unsatisfactory in the initial scale refinement procedure, suggesting that those items may be incapable of differentiating between factors. Table 3 shows nine factors. Factor 1 loaded six factors, and was named Internet adoption; this factor had a 13.23 percent variance. Items loaded in this factor included 'have access to Internet', 'access Internet at the Internet cafe', 'use Internet to sell and advertise the products', 'use of email to communicate with customers', 'Internet is useful for our businesses' and 'use of email to communicate with suppliers'.

Factor 2 was named factory visit and included items such as 'customers come collect products at the factory', 'customers visit the factory whenever they want to buy' and 'design and produce products according to customer specification'. It constituted 11.93 percent of the variance. The next factor, Factor 3, had 8.42 percent of the total variance and was named SCM challenges since it addressed some challenges that craft producers experiences. These included 'It is difficult to find a less expensive space for rental', 'renting out the space is very expensive' and 'transportation is one of the major challenges facing my businesses'.

Factor 4 was named factory space and included items such as 'There is not enough space to keep the stock' and 'do not have enough space to keep our products'. It comprised of 5.14 percent of the total variance. Factor 5 loaded two items 'Customers can order the product by email', 'customers can order the product via the Internet' and 'products can be couriered to international customers'. This factor was named online ordering. It constituted 4.60 percent of the total variance. 
The next factor, Factor 6, loaded 4.05 percent of the total variance and was named exhibition. It included two items such as 'customers can order the product at the exhibitions' and 'customers buy and collect products at the exhibition'. Factor 7 loaded three factors accounting for 3.92 percent of the total variance and included 'use rail transport to deliver our goods', 'use public transport to deliver goods to customers' and 'hire a delivery vehicle as and when there is an order to deliver'. It was named transportation (transport).

The next factor, Factor 8, loaded two items, was named resources and included 'use my own transport' and 'have my own space'. It loaded 3.66 percent of the total variance. This was followed by Factor 9, which loaded three factors and included items such as 'Produce products as and when there is an order', 'It takes us two weeks to produce products for big orders' and 'Produce products as and when we receive the order'. This was named production strategy and it constituted 3.46 percent of the total variance.

Factor 10 was named distribution and loaded two items. These included 'Products are delivered to the customers' and 'Customers can order the product over the phone'. The total percentage of variance was 3.01 percent. The last factor, Factor 11 also loaded two items and constituted 3.00 percent of the total variance. The items loading were 'Do not have access to production machinery' and 'cannot produce in bulk'. 
Table 3. Factor analysis

\begin{tabular}{|c|c|c|c|c|c|c|c|c|c|c|c|}
\hline & $\begin{array}{c}\text { Factor 1 } \\
\text { Internet } \\
\text { Adoption } \\
\end{array}$ & $\begin{array}{c}\text { Factor } 2 \\
\text { Factory visit }\end{array}$ & $\begin{array}{c}\text { Factor } 3 \\
\text { SCM } \\
\text { challenges }\end{array}$ & $\begin{array}{c}\text { Factor } 4 \\
\text { Factory } \\
\text { space }\end{array}$ & $\begin{array}{c}\text { Factor } 5 \\
\text { Order } \\
\text { placement }\end{array}$ & $\begin{array}{c}\text { Factor } 6 \\
\text { Exhibition }\end{array}$ & $\begin{array}{c}\text { Factor } 7 \\
\text { Transport }\end{array}$ & $\begin{array}{c}\text { Factor } 8 \\
\text { Resources }\end{array}$ & $\begin{array}{c}\text { Factor } 9 \\
\text { Production } \\
\text { strategy }\end{array}$ & $\begin{array}{c}\text { Factor } 10 \\
\text { Distribution }\end{array}$ & $\begin{array}{c}\text { Factor } 11 \\
\text { Resource } \\
\text { constraints }\end{array}$ \\
\hline $\begin{array}{l}\text { Use of email to communicate with } \\
\text { customers }\end{array}$ & .901 & .015 & -.033 & -.003 & -.023 & .016 & -.021 & .093 & .030 & .028 & -.018 \\
\hline Have access to own Internet & .850 & .058 & .038 & -.052 & -.013 & -.065 & -.028 & -.030 & .047 & .043 & .065 \\
\hline Internet is useful for our businesses & .845 & -.069 & .129 & -.040 & .051 & -.031 & .042 & -.069 & -.019 & -.092 & .030 \\
\hline $\begin{array}{l}\text { Use of email to communicate with } \\
\text { suppliers }\end{array}$ & .834 & -.036 & .038 & .049 & .042 & .073 & .109 & .091 & .007 & .006 & .114 \\
\hline $\begin{array}{l}\text { Use Internet to sell and advertise the } \\
\text { products }\end{array}$ & .814 & .064 & -.036 & .057 & -.031 & -.131 & -.084 & .031 & .041 & -.083 & -.040 \\
\hline Access Internet at the Internet café & .674 & -.184 & -.098 & .021 & -.075 & .187 & -.039 & -.120 & .021 & .115 & -.168 \\
\hline $\begin{array}{l}\text { Customers come collect products at the } \\
\text { factory }\end{array}$ & .014 & .782 & .234 & -.047 & .008 & .103 & -.019 & .015 & .040 & .026 & -.025 \\
\hline $\begin{array}{l}\text { Customers visit the factory whenever } \\
\text { they want to buy }\end{array}$ & -.048 & .779 & .026 & .092 & -.075 & .095 & .004 & .135 & .053 & .046 & .003 \\
\hline $\begin{array}{l}\text { Design and produce products according } \\
\text { to customer specification }\end{array}$ & -.068 & .537 & -.128 & .202 & .200 & -.004 & .106 & -.063 & .257 & .137 & -.068 \\
\hline $\begin{array}{l}\text { It is difficult to find a less expensive } \\
\text { space for rental }\end{array}$ & -.036 & -.104 & .776 & .063 & .026 & -.100 & .073 & .096 & .153 & .243 & .080 \\
\hline Renting out the space is very expensive & .061 & .152 & .766 & .212 & .087 & .014 & -.033 & .038 & .052 & -.051 & -.073 \\
\hline $\begin{array}{l}\text { Transportation is one of the major } \\
\text { challenges facing my businesses }\end{array}$ & -.033 & .047 & .546 & .207 & -.158 & .226 & .272 & -.144 & -.088 & -.151 & .114 \\
\hline $\begin{array}{l}\text { Do not have enough space to keep our } \\
\text { products }\end{array}$ & .027 & .082 & .075 & .779 & -.102 & .013 & -.029 & -.127 & .135 & .020 & .050 \\
\hline $\begin{array}{l}\text { There is not enough space to keep the } \\
\text { stock }\end{array}$ & -.080 & .076 & .305 & .647 & .077 & -.051 & .106 & .145 & .018 & .081 & .043 \\
\hline $\begin{array}{l}\text { Customers can order the product via the } \\
\text { Internet }\end{array}$ & -.025 & -.035 & -.042 & .084 & .833 & .032 & .028 & .082 & -.022 & .045 & -.069 \\
\hline $\begin{array}{l}\text { Customers can order the product by } \\
\text { email }\end{array}$ & -.037 & .028 & .088 & -.066 & .800 & .085 & -.129 & .016 & .112 & .223 & -.034 \\
\hline $\begin{array}{l}\text { Products are couriered to international } \\
\text { customers }\end{array}$ & .067 & .192 & -.008 & -.105 & .553 & .374 & .247 & .140 & -.059 & -.067 & .087 \\
\hline $\begin{array}{l}\text { Customers buy and collect products at } \\
\text { the exhibition }\end{array}$ & -.040 & .118 & -.025 & -.018 & .094 & .808 & .024 & .121 & .048 & -.103 & .125 \\
\hline
\end{tabular}


(Table 3 continued)

\begin{tabular}{|c|c|c|c|c|c|c|c|c|c|c|c|}
\hline & $\begin{array}{c}\text { Factor 1 } \\
\text { Internet } \\
\text { Adoption } \\
\end{array}$ & $\begin{array}{c}\text { Factor } 2 \\
\text { Factory visit }\end{array}$ & $\begin{array}{c}\text { Factor } 3 \\
\text { SCM } \\
\text { challenges }\end{array}$ & $\begin{array}{c}\text { Factor } 4 \\
\text { Factory } \\
\text { space }\end{array}$ & $\begin{array}{c}\text { Factor } 5 \\
\text { Order } \\
\text { placement }\end{array}$ & $\begin{array}{c}\text { Factor } 6 \\
\text { Exhibition }\end{array}$ & $\begin{array}{c}\text { Factor } 7 \\
\text { Transport }\end{array}$ & $\begin{array}{c}\text { Factor } 8 \\
\text { Resources }\end{array}$ & $\begin{array}{c}\text { Factor } 9 \\
\text { Production } \\
\text { strategy }\end{array}$ & \begin{tabular}{|c|} 
Factor 10 \\
Distribution
\end{tabular} & $\begin{array}{c}\text { Factor } 11 \\
\text { Resource } \\
\text { constraints }\end{array}$ \\
\hline $\begin{array}{l}\text { Customers can order the product at the } \\
\text { exhibitions }\end{array}$ & .020 & .156 & .081 & .102 & .151 & .741 & -.101 & -.023 & .181 & .297 & -.060 \\
\hline Use rail transport to deliver our goods & -.039 & -.032 & -.027 & -.124 & .036 & -.015 & .798 & .054 & .062 & -.120 & -.018 \\
\hline $\begin{array}{l}\text { Use public transport to deliver goods to } \\
\text { customers }\end{array}$ & .040 & .081 & .266 & .238 & -.177 & -.110 & .657 & -.133 & .091 & .218 & .122 \\
\hline $\begin{array}{l}\text { Hire a delivery vehicle as and when } \\
\text { there is an order to deliver }\end{array}$ & -.006 & -.016 & .050 & .511 & .158 & .122 & .545 & -.040 & -.010 & -.001 & -.026 \\
\hline Use my own transport & .033 & .003 & .043 & .110 & .084 & .032 & -.028 & .784 & -.008 & .002 & -.091 \\
\hline Have my own space & -.035 & .236 & .030 & -.197 & .099 & .081 & -.021 & .695 & .112 & .154 & .119 \\
\hline $\begin{array}{l}\text { Produce products as and when we } \\
\text { receive the order }\end{array}$ & .048 & .078 & -.106 & .020 & .002 & -.106 & .061 & -.067 & .808 & .041 & .015 \\
\hline $\begin{array}{l}\text { It takes us two weeks to produce } \\
\text { products for big orders }\end{array}$ & -.023 & -.007 & .132 & .010 & .028 & .216 & -.032 & .247 & .609 & -.037 & .169 \\
\hline $\begin{array}{l}\text { Produce products as and when there is } \\
\text { an order }\end{array}$ & .106 & .231 & .196 & .100 & .023 & .180 & .080 & .007 & .552 & .074 & .047 \\
\hline $\begin{array}{l}\text { Customers can order the product over } \\
\text { the phone }\end{array}$ & -.044 & .388 & .119 & -.058 & .154 & .210 & .058 & .004 & .131 & .667 & .186 \\
\hline $\begin{array}{l}\text { Produce products as and when we } \\
\text { receive the order }\end{array}$ & .032 & .166 & -.002 & .096 & .321 & -.101 & -.081 & .176 & -.017 & .545 & .110 \\
\hline Cannot produce in bulk & .013 & -.054 & .027 & -.015 & -.050 & .045 & .067 & -.199 & .092 & -.030 & .746 \\
\hline $\begin{array}{l}\text { Do not have access to production } \\
\text { machinery }\end{array}$ & .013 & .057 & .033 & .109 & -.013 & .037 & -.020 & .177 & .069 & .177 & .681 \\
\hline \% of variance Total variance: 64.46 & 13.23 & 11.93 & 8.42 & 5.14 & 4.60 & 4.05 & 3.92 & 3.66 & 3.46 & 3.01 & $\mathbf{3 . 0 0}$ \\
\hline Eigen values & 4.631 & 4.177 & 2.949 & 1.800 & 1.611 & 1.420 & 1.373 & 1.282 & 1.212 & 1.056 & 1.052 \\
\hline Factor reliability & .904 & .639 & .658 & .575 & .750 & .640 & .578 & .512 & .506 & .511 & .345 \\
\hline
\end{tabular}




\section{Implications and Recommendations}

This study investigated the supply chain practices of craft producers in Gauteng, South Africa. Craft producers place more emphasis on some supply chain activities than on others. Although craft producers have access to the Internet, there is no indication that the Internet is fully adopted by craft producers since some of them still access the Internet at the Internet café. It is still of limited use and confirms previous studies on Internet adoption by small businesses that found that the Internet is considered of moderate importance by small businesses (Cloete et al., 2002; Department of Sports, Arts, Culture \& Recreation, 2008; Al-Allak 2010). Craft producers could use internet to communicate out of stock situations with the customers and can also use it for order processing.

Customers visit the factory to collect their products, which is also necessary if products are designed according to customer specifications. Customers can also visit the factory to discuss their specifications with the craft producers. Craft producers face challenges regarding the availability of factory space and transportation. Where factory space is available it is too expensive for them to afford. This is why craft producers do not have sufficient space to keep their products. Transportation poses a challenge since some craft producers do not have their own transportation and have to either hire delivery vehicles or use public transport. These findings are similar to those of Voortman \& Makhitha (2014). Another challenge is the fact that craft producers do not have access to machinery and that they cannot produce in bulk. This is a disadvantage should they receive a big order that requires bulk production. However, craft producers could overcome this challenge by cooperating with other craft producers and co-produce the products in order to meet the quantity needs of customers.

Craft producers use various methods of order placement including ordering via the phone and the Internet. The use of a phone is convenient since this is the main method of communication on which craft producers rely. The fact that customers can order products at the exhibition also provides an opportunity for craft producers to reach more customers. This applies specifically to those who might not be able to visit the factory or reach them by phone and email. However, not all craft producers can afford to exhibit their products (Voortman \& Makhitha, 2014).

Craft producers also adopt various production strategies where products can produced as and when there is an order, but also produce to keep at the warehouse. Producing as and when there is an order helps them overcome the space challenge, since they might not be able to produce more products to keep at the warehouse due to shortage of space. It also takes craft producers two weeks to execute an order, which implies that producing as and when there is an order is more suitable for the businesses. However, craft producers might have to continue producing products to keep at the warehouse, especially standardised products that customers might want without delay. Since some customer require more products than craft producers have available to supply, producing to keep at the warehouse might help them keep the customers. Collaborating with other craft producers would mean that they are able to share the order with other craft producers. Hence they will be able to supply enough stock when required by the customer.

With regard to the distribution system followed, craft producers deliver to customers and customers can also collect the stock at the exhibition or the factory. They also deliver to international customers. Craft producers should continue practicing this system due to resource contains. However, they could improve the use of email as an order placement system.

Craft producers produce products to keep at the warehouse; however they incur high costs of keeping the stock. They could try to keep a balance the stock they keep at the warehouse with designing as and when there is an order. This implies they will keep the stock at a minimum level yet enough to supply customers when they need the stock.

\section{CONCLUSIONS}

Craft producers do not have an effective and efficient SCM. They face major challenges with transportation and availability of factory space. They adopt various production strategies by producing products to keep at the warehouse and also produce as and when there is an order. This implies they produce standardized products and also design products according to customer specifications. Although transportation poses a major challenge, craft 
producers explore other transportation methods such as use of public transportation to deliver products to customers. Craft producers use various order placement systems, however, they could improve the use of email and internet, which would enable them to target customers outside the provinces as well as those outside the country. Although some craft producers have their own factory space, this still pose a major challenge due to unavailability of space and the fact that available space is unaffordable. Craft producers produce products to keep at the warehouse, however, inventory keeping costs are high. They also avoid keeping stock at the warehouse by producing as and when there is an order.

\section{Ethical Considerations}

A structured questionnaire was distributed among craft producers in SA to investigate the supply chain practices and challenges in the craft industry. There were no questions of a personal and private nature. The questionnaire cover letter was attached, which requested craft producers to voluntarily take part into the research by completing the questionnaire. Data were treated with confidentiality.

\section{Limitations of the Study}

The study only targeted craft producers in Gauteng, South Africa and cannot be generalised to practices of craft producers in other provinces. It could also not be generalized to craft producers in other countries. Another study could investigate SCM practices of craft producers and small business in all provinces in South Africa as well as those in other countries. Furthermore other studies could investigate consumer behavior when buying crafts since no such studies exists in South Africa. The nature of the buyer supplier relationships in the craft industry supply chain could also be investigated.

\section{REFERENCES}

Al-Allak B. (2010). Evaluating the adoption and use of Internet-based marketing information systems to improve marketing intelligence: the case of tourism SMEs in Jordan. International Journal of Marketing Studies, 2(2),87-98.

Arbuthnot, J.J., Slama, M. \& Sisler, G. (1993). Selection criteria and information sources in the purchase decisions of apparel buyers of small retailing firms. Journal of Small Business Management, 12-23.

Arend, R.J. \& Winser, J.D. (2004). Small business and supply chain management: is there a fit? Journal of Business Venturing, 20, 403-36.

Batchelor S.J. \& Webb M. (2002). E-commerce options for third world craft producers: final technical report. [Internet: http://r4d.dfid.gov.uk/Output/183408/; downloaded 2013-12-04].

Bask, A.H. \& Juga, J. (2001). Semi-integrated supply chain: towards the new era of supply chain management. International Journal of Logistics: Research and Applications, 4(2), 137-5.

Bayraktar, E., Demirbag, M., Koh, S.C.L., Tatoglu, E \& Zaim, H. (2009). A causal analysis of the impact of information systems and supply chain management practices on operational performance: Evidence from manufacturing SMEs in Turkey. International. Journal of Production Economics, 122, 133-149.

Beheshti, H.M., Hultman, M., Jung, M.L., Opoku, R.A. \& Salehi-Sangari, E. (2007). Electronic supply chain management applications by Swedish SMEs. Enterprise Information

Systems, 1(2), 255-268.

Cloete E., Courtney S. \& Fintz J. (2002). Small enterprises' acceptance and adoption of e-commerce in the WesternCape province of South Africa. Electronic Journal of Information Systems in Developing Countries, 10(4), 1-13.2.

Bowersox, D.J., Stank, T.P \& Daugherty, P.J. (1999). Lean launch: managing product introduction risk through response-based logistics. Journal of Product Innovation Management, 16, 557-568.

Broembsen, M. (2011). Mediating from the margins: The role of intermediaries in facilitating participation in formal markets by poor producers and user. [Internet: http://www.tips. org.za /files

/u65/role_of_intermediaries_in_facilitating_markets_-_marlese_von_broembsen.pdf; downloaded 2013-1115]

Burt, D.A., Petcavage, S.D. \& Pinkerton, R.L. (2012). Proactive purchasing in the supply chain, New York: McGraw-Hil. 
Chan, F. \& Qi, H. (2003). An innovative performance measurement method for supply chain management. Supply Chain Management: An International Journal, 8(3), 209-23.

Collins, A. \& Burt, S. (2003). Market sanctions, monitoring and vertical coordination within retailer-manufacturer relationships: the case of retail brand suppliers. European Journal of Marketing, 37(5/6), 668-699.

Cooper, M.C. \& Ellram, L.M. (1993). Characteristics of supply chain management and the implications for purchasing and logistics strategy. The International Journal of Logistics Management, 4(2), 13-24.

Cooper, M.C., Lambert, D.M. \& Pagh, J.D. (1997). Supply chain management: More than a new name for logistics. International Journal of Logistics Management, 8(1), 1-14.

Cooper DR \& Schindler PS. (2006). Business research methods. 9th ed. New York, NY: McGraw-Hill.

Coviello, N.E. \& McAuley, A. (1999). Internationalization and the smaller firm: a review of contemporary empirical research. Management International Review, 39(3), 223-56.

De klerk S \& Kroon J. (2005). E-commerce adoption in South African businesses. South African Journal of Business Management, 36(1):33-40.

Department of Sports Arts Recreation \& Culture. (2007). Gauteng craft development strategy: 2007-2012. [Internet: www.sacr.gpg.gov.za/.../Strategies/ Craft\%20 Strategic\%20 Framework.pdf; downloaded 2013-12-04].

Department of Sports Arts Recreation \& Culture. (2008). Gauteng's creative industries: the craft sector. [Internet: http://www.britishcouncil.org/files/Low\% 20resolution\%20pdfs/Methodology\%20with\%20all\%20sectors/Methodology\%20 low\%20all \% 20sectors\% 20spreads.pdf; downloaded 2013-12-04].

Department of Economic Development. (2009). Creating an enabling environment for the growth of KZN Craft: KwaZulu-Natal Integrated Craft Hub Business Plan. Final, April. [Internet: http://led.co.za/sites/led.co.za/files/kzn_integrated_craft_hub_business_plan_2009 .pdf; 2013-11-15].

Department of Labour. (2008). The creative industries in South Africa: Sector studies research project. [Internet: http://www.labour.gov.za/DOL/downloads/documents/research-ocuments/Creative\%20Industries_DoL_ Report.pdf; downloaded 2014-07-09].

Department of Trade \& Industry. (2005). Sector development strategy: craft. [Internet: http://www.ccdi.org.za/research-andpublications/research/Customised\% 20Sector \%20Programme\%20for\%20Craft.pdf; downloaded 2013-12-04].

Dhurup, M \& Makhitha, K.M. (2014). Reflections on the constraints in entrepreneurial development among emerging survivalist and micro craft enterprises in Gauteng. Journal of Contemporary Management, 11, $230-250$.

Dludla, N.J. (2005). Marketing management strategies in roadside craft markets in Umkhanyakude Municipal area, Kwazulu-Natal. Unpublished masters dissertation, University of Kwazulu-Natal, Pietermaritzburg.

Elk, E. (2004). The South African Craft Sector, HSRC [online]. [Internet: http://www. capecraftanddesign.org.za/newsletters/newsletter/2008/CCDI_newsletter_Dec08.pdf; downloeaded 201311-15].

Field, A. \& Miles, J. (2010). Discovering statistics using SAS. London: Sage Publications.

Gilmore A, Gallagher D \& Henry S. (2007). E-marketing and SMEs: operational lessons for the future. European Business Review 19(30):234-247.

Grant, B., Lambert, M., Stock, R. and Ellram, M. (2006). Fundamentals of Logistics Management, Maidenhead: McGraw-Hill.

Grobler AT. (2005). Product development for community-craft projects in Mpumalanga. Pretoria: Tshwane University of Technology. (Masters in Textile Design and Technology -dissertation).

Gunasekaran, A \& Ngai, E.W.T. (2005). Build-to-order supply chain management: a literature review and framework for development. Journal of Operations Management 2, 423-451.

Hair, J. F., Black, W. C., Babin, B. J., \& Anderson, R. E. (2010). Multivariate data analysis: a global perspective. 7th ed. New Jersey, USA: Pearson Education.

Hay, D. (2008). The business of craft and crafting the business: strategies for success in the rural craft sector, 1-60. [Internet: http://www.tcd.ufl.edu/Data/Sites/44/media/ documents/tropilunch/2011/Businesof CraftHandbook-lowresolution.PDF; downloaded 2013-11-15].

Hilletofth, P. (2009). How to develop a differentiated supply chain strategy. Industrial Management and Data systems, 109(1), 16-33.

Hugo, W.M.J. \& Badenhorst-Weiss, J.A. (2013). Purchasing and supply chain management, Pretoria: Van Schaiks.

Kaizer \& Associates. (2005). Western Cape microeconomic development strategy: craft sector study. 
[Internet:http://www.ccdi.org.za/research-and-publications/research/Micro\%20

Economic\%20Development\%20Strategy\%20-MEDS-\%201.pdf; downloaded 2013-12-04].

Kim, J.-O. \& Mueller, C. W. (1978). Factor analysis: Statistical methods and practical issues. Beverly Hills, CA: Sage.

Koh, S.C.L., Demirbag, M., Bayraktar, E., Tatoglu, E \& Zaim, S. (2007). The impact of supply chain management practices on performance of SMEs. Industrial Management \& Data Systems, 107(1), 103-124.

Koh, S.C.L. \& Tan, K.H. (2006). Operational intelligence discovery and knowledge mapping approach in a supply network with uncertainty. Journal of Manufacturing Technology Management, 17(6), 687-99.

Lancioni, R.A., Smith, M.F. \& Olivia, T.A. (2000). The role of the Internet in supply chain

management. Industrial Marketing Management, 29(1), 45-56.

Lambert, D.M. \& Cooper, M.C. (2000). Issues in supply chain management', Industrial Marketing Management 29, $65-83$.

Lankford, W.M. (2004). Supply chain management and the Internet. Online Inform. Rev., 28(4), 301-305.

Lummus, R.R. \& Vokurka, R.J. (1999). Defining supply chain management: A historical perspective and practical guidelines. Industrial Management \& Data Systems 99(1), 11-17.

Malhotra NK. (2010). Marketing research: an applied orientation. 6th ed. New York, NY: Pearson.

Makhitha, K.M., Wiese, M \& Van Heerden, G. (2014). Craft retailers' supplier selection criteria -a key to market access. Journal of Contemporary Management, 11, 266 - 286.

Mangan, J., Lalwani, C., Butcher, T. \& Javadpour, R. (2012). Global logistics and supply chain management, West Sussex :John Wiley \& Sons.

MCCarthy A \& Mavundla K. (2009). Craft as an economic enterprise: strategies for alternative livelihoods in Kwazulu-Natal. [Internet: www.seda.org.za/Publications/ Publications/SEDA\%20SBM\%202009.pdf; downloaded2013-12-04].

Migiro A \& Ocholla DN. (2005). Information and communication technologies in small and medium scale tourism enterprises in Durban, South Africa. Information Development 21(4):283-294.

Obiri, M.N. (2002). Is market-led approach crucial to art and craft small and micro enterprises growth and sustainability in the Kwazulu-Natal Midlands? An unpublished masters dissertation, University of Natal.

O'Gorman, C. (2001). The sustainability of growth in small- and medium-sized enterprises. International Journal of Entrepreneurial Behaviour and Research, 7(2), 60-70.

Osmonbekov T, Bello DC \& Gilliland DI. (2002). Adoption of electronic commerce tools in business procurement: enhanced buying centre structure and processes. Journal of Business and Industrial Marketing 17(2/3):151166.

Pallent, J. (2010). SPSS survival manual : a step by step guide to data analysis using SPSS for Windows. McGraw Hill/Open University Press.

Pereira T, Shackleton C \& Shackleton S. (2006). Trade in reed based craft products in rural villages in the Eastern Cape. South Africa, Development Southern Africa 23(4):477-495.

Pienaar, W.J. \& Vogt, J.J. (2012). Business logistics management: A supply chain perspectives, 4th ed. Cape Town: Oxford University Press.

Quayle, M., (2003). A study of supply chain management practice in the UK industrial SMEs', Supply Chain Management 8(1), 79-86.

Rankin C. (2007). Development by design - an example in the South African craft industry: The due-south travel guide. Pretoria: University of Pretoria. [Masters-dissertation].

Rogerson C.M. (2010). The enterprise of craft: constraints and policy challenges in South Africa, Acta Academica, 42(3), 115-144.

Sellschop, S., Goladblatt, W. \& Hemp, D. (2005). Craft South Africa. Pretoria, South Africa.: Pan Macmillan.

Southafrica Web. n.d. Crafts in South Africa. [ http://www. southafricaweb.co.za/page/crafts-south-africa; downloaded 2013-11-15].

Sujee, N. (2008). Increasing South Africa's contribution to global trade in craft. Unpublished masters dissertation, University of Stellenbosch.

Tabachnick, B. G., \& Fidell, L. S. (2001). Using multivariate statistics. 4th ed. International student edition. Need Ham Heights, Mass: Pearson Education Company.

Tan, K.C. (2006). Supply Chain Management: Practices, Concerns, and Performance Issues Supply Chain Management: Practices, Concerns, and Performance IssuesThe Journal of Supply Chain Management, 8(4), $42-53$. 
Tan, K.C. (2001). A framework of supply chain management literature. European Journal of Purchasing and Supply Management 7, 39-48.

Thakkar, J., Kanda, A \& Deshmukh, S.G. (2008). Supply chain management in SMEs: development of constructs and propositions. Asia Pacific Journal of Marketing and Logistics, 20(1), 97 - 131.

Thompson, R.H. \& Manrodt, K.B. (1997). Supply Chain Management: Teaming for Success, Ernst \& Young LLP and The University of Tennessee, Knoxville, TN.

Tracey, M., Jeen-Su Lim, J.S \& Vonderembse, M.A. (2005). The impact of supply-chain management capabilities on business performance. Supply Chain Management: An International Journal, 10(3),179 - 191.

United Nations Educatio.nal Scientific \& Cultural Organisation. (1997). International symposium on crafts and the international markets: trade and customs codification. [Internet:http://unesdoc.unesco.org/images/0011/ 001114/111488eo.pdf; downloaded 2013-12-04].

Vaaland, T.I. \& Heide, M. (2007). Can the SME survive the supply chain challenges?, Supply Chain Management: An International Journal 1(1), 20-31.

Voortman, C \& Makhitha, K.M. (2014). The alignment of product strategy to supply chain practices of craft businesses in Gauteng Province, South Africa. Journal of Transport and Supply Chain Management, 8(1), $1-11$.

Wesgro. (2000). Wesgro background on the craft industry in the Western Cape. [Internet: http://www.ccdi.org.za/ research-and-publications/research/Craft $\% 20$ Industry \%20in\%20 the\% 20Western $\% 20$ Cape.pdf; downloaded2013-12-04].

Zikmund, W.G \& Babin, B.J. (2010). Exploring marketing research. $10^{\text {th }}$ Edition. USA:Thomson/South-Western. 